\title{
Community Based Case Control Study on Effect of Nutrition Education Intervention on Predictors and Prevalence of Anaemia among Children aged 6 to 59 months in Pastoralist and Agro-Pastoralist community of Somali Region, Eastern Ethiopia
}

Rashid Guled ( $\square$ rashidabdi114@gmail.com )

Jigjiga University

Nik Mamat

International Islamic University Malaysia

Wan Azdie Abu Bakar

International Islamic University Malaysia

Tefera Belachew

Jimma University

Nega Assefa

Haramaya University

\section{Research Article}

Keywords: Anaemia, Children, Breastfeeding, Complementary feeding, Somali Region, Ethiopia

Posted Date: December 29th, 2020

DOI: https://doi.org/10.21203/rs.3.rs-124575/v1

License: (9) (1) This work is licensed under a Creative Commons Attribution 4.0 International License.

Read Full License 


\section{Abstract}

Background Anaemia is one of the major public health problems. It affects over 1.6 billion individuals of all age groups globally. Ethiopia is one of the seriously affected countries. Hence, the aim of this study is to assess the effect of nutrition education intervention (NEI) on anaemia prevalence and its predictors of preschool children in Pastoralist and Agro-pastoralist community of Somali Region, Eastern Ethiopia.

Methods A group randomized controlled trial was conducted among 404 paired children 6-59 months to mothers/caregivers in two phases. A face-to-face interview for mothers/caregivers using a semi structured questionnaire and haemoglobin measurement of the children was done. The some procedure were repeated after eight months of NEl. Blood haemoglobin $(\mathrm{Hb})$ level of the children were measured using Hemocue 301. SPSS version 20 was used, a chi-square test for categorical and t-test (independent and repeated paired) for continuous variables were performed.

Results the overall anaemia prevalence was decreased from $72 \%$ at baseline and $51 \%$ at post intervention. The majority of this change had occurred in intervention group (79.3-44.8\%). The mean $\mathrm{Hb}$ level score difference of the difference (DOD) were significantly improved $(-1.163, p<0.001)$ after NEI. While, intervention group showed significantly higher increment of $\mathrm{Hb}$ level $(9.4 \mathrm{~g} / \mathrm{dl}-10.6 \mathrm{~g} / \mathrm{dl}, \mathrm{p}<$ 0.001).

Conclusion The NEI has been observed effective and significantly improved the mean haemoglobin level and the anaemia prevalence in intervention group. Therefore, behaviour change communication, using religious leaders and other potential peoples advocating the use of locally available, accessible and affordable nutritious foods with proper infant and young child feeding and basic health services are highly effective to tackle the children's anaemia status.

\section{Background}

Anaemia is defined as a low level of haemoglobin concentration in the blood. It's one of the major public health problems that affects over one and half billion individuals of all age groups, every year all over the world. The overall global anaemia prevalence in preschool children reported $47.4 \%$. While, in Africa it is reported $67.6 \%(1,2)$. In 2011 about 273.2 million children below five years of age were affected by anaemia, of which around two third (62.3\%) occurs in Sub-Saharan Africa. Anaemia in children alters the motor, cognitive, and growth development, and impairs the health, and socio-economic improvement of the community (3-6). 
Table 1

Anaemia prevalence of children below five years of age of different studies in Sub-Saharan Africa

\begin{tabular}{|llllll|}
\hline Authors (Reference) & Country & \multicolumn{4}{l}{ Anaemia prevalence (\%) } \\
\cline { 3 - 6 } & & Overall & Mild & Moderate & Severe \\
\hline Ewusie et al., 2014 & Ghana & 78.4 & 22.6 & 48.0 & 7.8 \\
\hline Green et al., 2011 & Uganda & 68.9 & NR & NR & 3.7 \\
\hline Mahmoud et al., 2014 & Sudan & 86.0 & NR & NR & 22.0 \\
\hline Semedo et al., 2014 & Cape Verde & 51.8 & NR & NR & NR \\
\hline Magalhães \& Clements, 2011 & Western Africa & 78.0 & 21.0 & 49.0 & 7.0 \\
\hline Magalhães \& Clements, 2011 & Eastern Africa & 63.0 & 24.0 & 34.0 & 4.0 \\
\hline Sumbele et al., 2016 & Cameroon & 67.6 & 23.6 & 29.6 & 8.3 \\
\hline Onyemaobi \& Onimawo, 2011 & Nigeria & 70.5 & 38.0 & 31.8 & 0.8 \\
\hline NR = Not reported & & & & & \\
\hline
\end{tabular}

Despite the effort of Sub-Saharan countries including Ethiopia to decrease the child mortality rates, the anaemia prevalence of children below five years is still more than $40 \%$ (Table 1 ), ranging from $42-91 \%$ $(7-12,14,15)$. The main predictors of anaemia in preschool children in Ethiopia were age of the child, wealth index, child nutritional status $(14,16,17)$, maternal education $(16,18,19)$, maternal health status $(16,18)$, maternal occupation (housewife and/or daily labourer), low family income, in adequate food intake (19), low vitamin A supplementation, de-wormed, area of residence (rural), mother's age (younger) (16), un-safe water supply, and poor environmental sanitation (18).

In Somali Region the anaemia prevalence is higher than the notional level accounting $82.6 \%(14)$. The nutrition education, Iron supplementation, de-worming and targeting other cause of anaemia is important after six months of life to maintain the normal growth and development of the child and reduce the high child morbidity and mortality (20-22). Such information is little or unavailable in this community.

Therefore, this study was designed to document the effect of NEI on anaemia status of the children 6-59 months in Shabelle Zone of Somali Regional State, Eastern Ethiopia

\section{Methods}

\section{Study design and period}

A group randomized controlled trail conducted in August, 2018 from 397 paired child-mothers/caregivers in Gode and Adadle districts of Shabelle zone, Somali regional state. After eight months of NEl in Adadle 
district, a post interventional study was conducted in August 2019 from 404 paired childmothers/caregivers.

The NEI programme was designed and conducted using social cognitive theory (SCT). This theory "plays in the adoption, initiation, and maintenance of health behaviours" (23). The NEI programme was intended to improve the knowledge, attitude and skills of mothers/caregivers regarding the child feeding practices, with the end result of improvement of the child anaemia status. The intervention group were given scheduled health education sessions. Topics related to nutrition were taught to intervention group by presentation, role play, and demonstrations by trained nurses, health extension workers, and primary health care workers for over eight months, two sessions per week. In addition, display of key messages on the health centres, clinics and health posts were done. Community social mobilizers and religious leaders were also involved. The main topics given were; nutrition for pregnant mother, delivery, correct breastfeeding (initiation, EBF, and duration), positioning and attachment, feeding of low birth weight, complementary feeding (initiation, type, food hygiene \& safety, and preparation), including snacks and feeding during sickness, food pyramid including fruits and vegetable, and specific health services like; vaccination, rewarming, vitamin A, ITNs usage and environmental sanitation, treating sick child, each topic was taught for at least sixty minutes. While, Gode district (control group) remain getting only the routine health service activities.

\section{Data collection procedure and measurement}

A semi structured questionnaire was prepared in English and translated in to Somali language and again back to English, and checked by other person who speaks both languages to ensure its consistency. Haemoglobin level of the children age was measured using Hemocue301, this makes easy to signpost the anaemia status of the children. Data was collected by degree and diploma nurses after two days training and one day pilot test, in both pre and post intervention study period. To ensure the data clarity and completeness, during data collection continuous monitoring and checking on daily bases were done by the principal investigator and the team supervisors.

\section{Data analysis}

The data were coded, double entered, checked for missing values and outliers, and analysed using SPSS (SPSS Inc. version 20). A descriptive and inferential statistics were used. The specific statistical analysis used here include; Chi-square and fishers exact tests for categorical variables and t-test for continuous variables (independent t-test and paired -repeated measure- $t$-test), after checking the assumptions.

\section{Ethical considerations}

Ethical clearance was obtained from the International Islamic University Malaysia Research Ethical Committee (IREC). A written support letter was also obtained from Ethiopia Federal Ministry of Health $(\mathrm{FMOH})$, Somali Regional Health Bureau (SRHB) and Shabelle Zone administrative office. The purpose of the study was clearly explained to the participants and informed consent was obtained from the mothers/caregivers, prior to the data collection. This type of consent were presented, discussed with ethical, and supervisory committees, and agreed upon. These was due to the fact that the majority of the 
mothers/caregivers in the study area were illiterate (cannot read and write). Since, our data collection method has no an evidence to harm the participants. It was only interview to the mothers/caregivers, and minimal peripheral capillary blood sample by finger brick for anaemia detection. The participants were encouraged to be honest as much as possible. The interviewers/data collectors were given a written statement to read and sign after the acceptance of the participants. Confidentiality was assured by keeping all information in a proper place. In addition, if a sick and/or anaemic child is seen, the team would send to the nearest health facility for assistance.

\section{Results}

A total of 397 and 404 children between the ages of 6-59 months and their mothers/caregivers in pre and post intervention respectively, were enrolled in the study. The mean ( \pm SD) age of the children in intervention and control groups from pre and post intervention was 22.2(12) \& 33.7(12) and 28(14) \& $36.6(13.5)$ months, respectively. The male to female ratio of the children was $1: 1.15$. The majority of the participants were from rural resident. More than $80 \%$ of the mothers/caregivers were illiterate and housewives, with mean $( \pm S D)$ age group of mothers/caregivers in intervention and control groups from pre and post intervention was 28(6) \& 29(6) and 29.5(9.5) \& 30(9) years, respectively. All respondents were Muslim by religion, and Somali by Ethnic group. The mean $( \pm S D)$ family size, and number of under -five children in the family were 6(2), and 2(0.7) persons, respectively. Main source of income in intervention group were from farm and livestock, whereas trade and daily labourer was in control group (Table 2).

\section{Effect of NEl on anaemia in children}

The overall anaemia prevalence in children 6-59 months of age was $72 \%$ at baseline, this was declined after eight months of NEI to $51 \%$. The majority of this change had occurred in intervention group, which makes a big improvement from $79.3 \%$ of anaemia prevalence at baseline to $44.8 \%$ at post intervention. Unlike, the control group had only showed a minimal decrease of anaemia prevalence from $64.9 \%$ at baseline to $57.2 \%$ at the post intervention. This was statistically significant difference $(p<0.01)$ between pre and post intervention. Regarding the severity of the problems, the moderately and severely anaemic children were dramatically decreases by more than half in intervention group from $54.7 \%$ \& $5.4-22.7 \%$ \& $1.5 \%$, respectively (Table 3 ). 
Table 2

Socio-demographic and economic characteristics among children 6-59 months by district between pre and post intervention

\begin{tabular}{|c|c|c|c|c|c|}
\hline \multicolumn{2}{|l|}{ Variables } & \multicolumn{2}{|l|}{ Baseline } & \multicolumn{2}{|c|}{ Post intervention } \\
\hline & & \multirow{2}{*}{$\begin{array}{l}\text { Adadle }(n= \\
\text { 203) }\end{array}$} & \multirow{2}{*}{$\begin{array}{l}\text { Gode } \\
(n=194)\end{array}$} & \multirow{2}{*}{$\begin{array}{l}\text { Adadle } \\
(n= \\
203)\end{array}$} & \multirow{2}{*}{$\begin{array}{l}\text { Gode } \\
(n=201)\end{array}$} \\
\hline & & & & & \\
\hline & & (\%) & (\%) & (\%) & (\%) \\
\hline \multirow[t]{3}{*}{ Residence } & \multirow{2}{*}{$\begin{array}{l}\text { Urban/Semi- } \\
\text { urban }\end{array}$} & 25.1 & 32.5 & 25.1 & 33.48 \\
\hline & & 74.9 & 67.5 & 74.9 & 66.2 \\
\hline & Rural & & & & \\
\hline \multirow[t]{2}{*}{ Child Sex } & Male & 53.7 & 53.1 & 54.2 & 52.7 \\
\hline & Female & 46.3 & 46.9 & 45.8 & 47.3 \\
\hline \multirow[t]{6}{*}{ Child age } & $<12$ & 7.4 & 5.7 & 0 & 0 \\
\hline & $12-23$ & 43.3 & 29.4 & 7.5 & 5.9 \\
\hline & $24-35$ & 28.1 & 25.8 & 43.8 & 30.8 \\
\hline & $36-47$ & 10.3 & 21.1 & 28.4 & 27.0 \\
\hline & $48-60$ & 10.8 & 18.0 & 20.4 & 36.2 \\
\hline & Mean \pm SD & $22.2 \pm 12.2$ & $\begin{array}{l}27.8 \pm \\
14.1\end{array}$ & $\begin{array}{l}33.7 \pm \\
12\end{array}$ & $\begin{array}{l}36.6 \pm \\
13.5\end{array}$ \\
\hline \multirow[t]{4}{*}{ Family size } & $1-3$ & 9.4 & 5.2 & 11.3 & 10.4 \\
\hline & $4-6$ & 49.8 & 50.2 & 49.8 & 44.6 \\
\hline & $\geq 7$ & 53.7 & 49.7 & 38.9 & 45.0 \\
\hline & Mean \pm SD & $5.9 \pm 1.9$ & $6.2 \pm 2.1$ & $\begin{array}{l}6.1 \pm \\
1.96\end{array}$ & $6.4 \pm 2.2$ \\
\hline \multirow[t]{4}{*}{ Number $<5$ children family } & 1 & 22.2 & 18.6 & 25.6 & 20.9 \\
\hline & 2 & 59.1 & 60.3 & 53.2 & 59.7 \\
\hline & $\geq 3$ & 18.7 & 21.1 & 21.2 & 19.4 \\
\hline & Mean \pm SD & $1.98 \pm 0.67$ & $\begin{array}{l}2.0 \pm \\
0.66\end{array}$ & $\begin{array}{l}2.0 \pm \\
0.79\end{array}$ & $2.0 \pm 0.69$ \\
\hline
\end{tabular}




\begin{tabular}{|c|c|c|c|c|c|}
\hline \multirow[t]{4}{*}{ Variables } & & \multicolumn{2}{|l|}{ Baseline } & \multicolumn{2}{|c|}{ Post intervention } \\
\hline & & \multirow{2}{*}{$\begin{array}{l}\text { Adadle }(n= \\
\text { 203) }\end{array}$} & \multirow{2}{*}{$\begin{array}{l}\text { Gode } \\
(n=194)\end{array}$} & \multirow{2}{*}{$\begin{array}{l}\text { Adadle } \\
(n= \\
203)\end{array}$} & \multirow{2}{*}{$\begin{array}{l}\text { Gode } \\
(n=201)\end{array}$} \\
\hline & & & & & \\
\hline & & (\%) & (\%) & (\%) & (\%) \\
\hline \multirow[t]{5}{*}{ caregiver's age } & $\leq 18$ & 4.9 & 3.1 & 0.5 & 1.5 \\
\hline & $19-25$ & 29.6 & 37.9 & 25.6 & 33.3 \\
\hline & $26-35$ & 53.2 & 41.5 & 57.1 & 43.3 \\
\hline & $>35$ & 12.3 & 17.4 & 16.7 & 21.9 \\
\hline & Mean \pm SD & $28.2 \pm 5.9$ & $\begin{array}{l}29.5 \pm \\
9.5\end{array}$ & $\begin{array}{l}29.2 \pm \\
5.9\end{array}$ & $29.9 \pm 9.1$ \\
\hline \multirow[t]{2}{*}{ caregiver's education } & Illiterate & 81.8 & 93.3 & 81.8 & 92.5 \\
\hline & Literate & 18.2 & 6.7 & 18.2 & 7.5 \\
\hline \multirow[t]{2}{*}{ caregiver's occupation } & House wife & 84.2 & 85.1 & 84.2 & 84.6 \\
\hline & $\begin{array}{l}\text { Farmer \& } \\
\text { others` }^{\wedge}\end{array}$ & 15.8 & 14.9 & 15.8 & 15.4 \\
\hline \multirow[t]{2}{*}{ Source of income } & Livestock/farm & 52.2 & 38.1 & 67.0 & 37.0 \\
\hline & Salary \& others ${ }^{\#}$ & 47.8 & 61.9 & 33.0 & 62.2 \\
\hline \multirow[t]{2}{*}{ Source of drinking water } & Protected & 0.5 & 23.2 & 12.3 & 19.9 \\
\hline & Unprotected & 99.5 & 76.8 & 87.7 & 80.1 \\
\hline \multirow{2}{*}{$\begin{array}{l}\text { Disease during last two } \\
\text { weeks }\end{array}$} & Yes & 79.8 & 75.8 & 59.1 & 70.1 \\
\hline & No & 20.2 & 24.2 & 40.9 & 29.9 \\
\hline \multirow[t]{2}{*}{ ITNs use of $<5$ children } & Yes & 74.9 & 89.2 & 87.7 & 75.1 \\
\hline & No & 25.1 & 10.8 & 12.3 & 24.9 \\
\hline \multirow[t]{2}{*}{ Child Immunized } & Yes & 86.7 & 93.8 & 98.0 & 92.4 \\
\hline & No & 13.3 & 6.2 & 2.0 & 7.6 \\
\hline \multirow[t]{2}{*}{ Child Dewormed } & Yes & 17.2 & 35.6 & 54.2 & 50.3 \\
\hline & No & 82.8 & 64.4 & 45.8 & 49.7 \\
\hline \multirow[t]{2}{*}{ Child Vit A supplement } & Yes & 19.2 & 49.5 & 55.7 & 53.5 \\
\hline & No & 80.8 & 50.5 & 44.3 & 46.5 \\
\hline
\end{tabular}


Baseline

$\begin{array}{llll}\begin{array}{l}\text { Adadle }(n= \\ \text { 203 })\end{array} & \text { Gode } & \text { Adadle } & \text { Gode } \\ & (n=194) & \begin{array}{l}(n= \\ 203)\end{array} & (n=201)\end{array}$

(\%)
(\%)

(\%)
(\%)

Adadle $=$ intervention, Gode $=$ control ${ }^{\#}$ Trade \& daily labourer, ${ }^{\wedge}$ merchant, farmer, daily labourer, employee

Table 3

Anaemia prevalence and severity status of children 6-59 months comparing pre and post intervention of intervention and control groups in Gode and Adadle Districts

\begin{tabular}{|c|c|c|c|c|}
\hline \multirow[t]{2}{*}{ Variables } & \multicolumn{2}{|l|}{ Baseline } & \multicolumn{2}{|l|}{ Post intervention } \\
\hline & $\begin{array}{l}\text { Intervention }(n= \\
\text { 203) }\end{array}$ & $\begin{array}{l}\text { Control }(n= \\
194)\end{array}$ & $\begin{array}{l}\text { Intervention }(\mathrm{n}= \\
\text { 203) }\end{array}$ & $\begin{array}{l}\text { Control }(n= \\
201)\end{array}$ \\
\hline $\begin{array}{l}\text { HB level } \\
(\mathrm{g} / \mathrm{dl})\end{array}$ & $\%$ & $\%$ & $\%$ & $\%$ \\
\hline$\geq 11$ & $20.7^{* \star}$ & 35.1 & $55.2^{\star}$ & 42.8 \\
\hline $10-10.9$ & 19.2 & 20.6 & 20.7 & 19.9 \\
\hline $7-9.9$ & 54.7 & 36.6 & 22.7 & 31.8 \\
\hline$<7$ & 5.4 & 7.7 & 1.5 & 5.5 \\
\hline \multicolumn{5}{|c|}{ Anaemia prevalence } \\
\hline No & 20.7 & 35.1 & 55.2 & 42.8 \\
\hline Yes & $79.3^{\star \star}$ & 64.9 & $44.8^{*}$ & 57.2 \\
\hline \multicolumn{5}{|c|}{$\star \star \mathrm{p}<0.01, * \mathrm{p}<0.05$ Intervention $=$ Adadle Control $=$ Gode } \\
\hline
\end{tabular}

The anaemia overall mean score of paired t-test were showed statistically significant improvement $(\mathrm{p}<$ 0.001) in both intervention and control groups. But, the independent $t$-test between intervention and control groups at pre and post intervention, the intervention group showed statistically significant improvement of mean $\mathrm{Hb}$ level $(-1.163, \mathrm{p}<0.001)$ (Table 4). 
Table 4

Mean and mean differences of pre and post intervention anaemia of children 6-59 months between intervention and control groups in Gode and Adadle districts

\begin{tabular}{|c|c|c|c|}
\hline Variable & Paired sample t-test & & $\begin{array}{l}\text { Independent sample t- } \\
\text { test }\end{array}$ \\
\hline $\begin{array}{l}\text { Intervention }(n= \\
201)\end{array}$ & Control $(n=185)$ & \multirow[t]{2}{*}{$\begin{array}{l}\text { Mean Hb level score DOD } \\
(95 \% \mathrm{Cl})\end{array}$} & \multirow{5}{*}{$-1.163(-1.263,-1.062)^{\star \star \star}$} \\
\hline $\begin{array}{l}\text { Mean Hb level score } \\
\pm(\mathrm{SD})\end{array}$ & $\begin{array}{l}\text { Mean Hb level score } \\
\pm(\mathrm{SD})\end{array}$ & & \\
\hline Anaemia & $9.399(1.58)$ & $9.897(1.87)$ & \\
\hline Pre-test & $11.607(1.89)^{\star \star \star}$ & $10.943(1.91)^{\star \star \star}$ & \\
\hline Post-test & & & \\
\hline
\end{tabular}

\section{Discussion}

In this study the overall prevalence of anaemia in children 6-59 months was dramatically dropped after eight months of NEl from $72 \%$ at baseline (24) to $51 \%$ at post intervention. The majority of this change were contributed by intervention group that showed a marked deference at pre and post intervention, while percentage of children without anaemia increased from $20.7 \%$ at baseline to $55.2 \%$ at post intervention. Unlike control group, which showed a minimal decrease of prevalence from $64.9-57.2 \%$ at the same period. This was matched with the results obtained from other studies, which showed decrease of anaemia prevalence after nutrition intervention (25-30).

In the present study the mean haemoglobin concentration level score was significantly increased after NEI in both intervention and control groups. However, the increment were more than twice higher in intervention group (i.e. $2.21 \mathrm{~g} / \mathrm{dl}$ mean score increase), compared to control group of only $(1.0 \mathrm{~g} / \mathrm{dl}$ mean score increase) between pre and post intervention period. This marked improvement of mean haemoglobin level score in the intervention group was parallel with other studies in different part of the developing countries $(20,25,31-33)$. This indicates that the NEI has been conducted effectively. It is therefore, important to maintain/sustain the effort of NEl for the improvement of anaemia status of the children.

\section{Conclusion}

A NEl targeting nutritional status including anaemia and its contributing factors for the children below five years were performed. This strategic NEI was found effective in improving the anaemia status of the children. The NEI to words mothers/caregivers behaviour related to child feeding practices with optimal 
IYCF approach using the accessible, available and affordable resources; such as breast milk, animal source foods, indigenous fruits and vegetable etc. In addition, promoting child immunization, de-worming, vitamin $A$, and Iron supplementations, and proper ITNs utilization has worked and improved the anaemia status of the target children. A combination of these were significantly improved the $\mathrm{Hb}$ level of the children.

Finally, this intervention showed promising outcome, if further scaled up and adapted to other districts in the zone, as well as other areas in the region. It may therefore, bring dramatic change in improving the health and growth of the children below five years of age and decrease the morbidity and mortality caused by this deadly problem. It also showed that the problem can be tackled by behaviour change communication (BCC) using locally available, accessible and affordable nutritious foods and other resources. We strongly suggest to strengthen the community based nutrition programme (CBN), which is commonly practiced in the highland areas of the country and to extend this CBN to this community and other districts of Somali region in general. We also recommend refresher training to the health workers on CBN and on optimal IYCF strategy. Furthermore, the relationship between the health professionals and community should be strengthen. Religious leaders play key role on NEI and utilization of other basic health services because they are highly influential and respectful by the community. Mobilizing them and involving them on CBN activities has been effective and fruitful. Others that can also be utilized include; mothers/caregivers (mother to mother, and one to five developmental arm networks), women and youth associations, teachers, and school children.

\section{List Of Abbreviations}

ANOVA Analysis of Variance

BBC Behaviour change communication

CBN Community Based Nutrition

DDS Dietary Diversity Score

DOD Difference of the Difference

EHDS Ethiopia Health and Demographic Survey

FMOH Federal Ministry of Health

g/dl Gram per decilitre

Hb Haemoglobin Level

ITNs Insecticide Treated Nets

IREC IIUM Research and Ethical committee 
IYCF Infant and Young Child Feeding

NEI Nutrition Education Intervention

SD Standard Deviations

SPSS Statistical Package for Social Science

SRHB Somali Regional Health Bureau

UNICEF United Nations Children Fund

WHO World Health Organization

\section{Declarations}

\section{Ethical approval and consent to participants}

Ethical approval Research approval was obtained from international Islamic University Malaysia Ethical Committee, Ref. number: IIUM310/G20/4/14-37, Dated: 26th December 2013/22 Safar 1435H. A verbal informed consent was obtained from the mothers/caregivers, prior to the data collection.

\section{Consent to publish}

Not applicable

\section{Availability of data and materials}

The datasets used in this study are available from the corresponding author on reasonable request

\section{Guideline}

We confirm that all methods were carried out in accordance with the guidelines and regulations.

\section{Competing Interest}

The authors declared that there are no any competing interest

\section{Funding}

No specific funding agent/affirm for this study

\section{Authors Contribution}

RAG brought the inception of the study, designed the proposal, managed data collection, analysis and write up. NM, TB, WM and NA worked closely with RAG in the refinement of the proposal, fieldwork, analysis, and write up. All authors read and approved the submission of this paper. 


\section{Acknowledgement}

Authors would like to thank SRHB and Gode hospital administrator for supporting the study, data collectors and supervisors for their diligence in the work, and Sado Farah for helping the data entry process.

\section{References}

1. WHO. Worldwide prevalence of anaemia 1993 - 2005: WHO Global Database on Anemia. de Benoist B, McLean E, Egli I, Cogswell M, editors. Geneva; 2008.

2. WHO. the Global Prevalence of Anaemia in 2011 [Internet]. WHO. 2015. Available from: http://apps.who.int/iris/bitstream/10665/177094/1/9789241564960_eng.pdf?ua=1

3. Haidar J. Prevalence of anaemia, deficiencies of iron and folic acid and their determinants in ethiopian women. J Heal Popul Nutr. 2010;28(4):359-68.

4. Sanou D, Ngnie-teta I. Risk Factors for Anemia in Preschool Children in Sub-Saharan Africa [Internet]. www.intechopen.com. 2012. p. 171-90. Available from: isbn: 978-953-51-0138-3

5. Pasricha SR, Hayes E, Kalumba K, Biggs BA. Effect of daily iron supplementation on health in children aged 4-23 months: A systematic review and meta-analysis of randomised controlled trials. Lancet Glob Heal [Internet]. 2013;1(2):e77-86. Available from: http://dx.doi.org/10.1016/S2214109X(13)70046-9

6. Gutema B, Adissu W, Asress Y, Gedefaw L. Anemia and Associated Factors Among School-Age Children in Filtu, Somali region, Southeast Ethiopia. BMC Hematilogy. 2014;14(13).

7. Ewusie JE, Ahiadeke C, Beyene J, Hamid JS. Prevalence of anemia among under-5 children in the Ghanaian population: estimates from the Ghana demographic and health survey. BMC Public Health [Internet]. 2014;14(1):626-34. Available from: http://www.biomedcentral.com/1471-2458/14/626

8. Green HK, Sousa-figueiredo JC, Basáñez M. Anaemia in Ugandan preschool-aged children: the relative contribution of intestinal parasites and malaria. Parasitology. 2011;138:1534-45.

9. Mahmoud HH, Muddathir AM, Osman SEM, Alkhawad MA, Mohamed AK, Elmubarak EE, et al. Iron Deficiency Anemia among Children under Three years in Kassala, Eastern Sudan. Sudan J Public Heal. 2014;9(1):33-7.

10. Semedo RML, Santos MMAS, Baião MR, Luiz RR, Veiga G V. Prevalence of Anaemia and Associated Factors among Children below Five Years of Age in Cape Verde, West Africa. J Heal Popul NUTR. 2014;32(4):646-57.

11. Magalhães RJS, Clements AC. Spatial heterogeneity of haemoglobin concentration in preschool-age children in sub-Saharan Africa. Bull World Health Organ. 2011;89(6):459-68.

12. Sumbele IUN, Sama SO, Kimbi HK, Taiwe GS. Malaria , Moderate to Severe Anaemia , and Malarial Anaemia in Children at Presentation to Hospital in the Mount Cameroon Area: A Cross-Sectional Study. Hindawi Publ Corp. 2016; 
13. Onyemaobi GA, Onimawo IA. Anaemia Prevalence among Under-five Children in Imo State , Nigeria. Aust J Basic Appl Sci. 2011;5(2):122-6.

14. CSA. Ethiopia Demographic and Health Survey 2016: Key Indicators Report. Addis Ababa, Ethiopia; 2016.

15. Scott SP, Chen-Edinboro LP, Caulfield LE, Murray-Kolb LE. The impact of anemia on child mortality: An updated review. Nutrients. 2014;6(12):5915-32.

16. Habte D, Asrat K, Magafu MGMD, Ali IM, Benti T, Tegegne G, et al. Maternal Risk Factors for Childhood Anaemia in Ethiopia. Afr J Reprod Health. 2013;17(3):110-8.

17. Gebreegziabiher G, Etana B, Niggusie D. Determinants of Anemia among Children Aged 6 - 59 Months Living in Kilte Awulaelo Woreda, Northern Ethiopia. Hindawi Publ Corp. 2014;

18. Adish A, Esrey S, Gyorkos T, Johns T. Risk factors for iron deficiency anaemia in preschool children in northern Ethiopia. Public Heal Nutr. 1999;2(3):243-52.

19. Assefa S, Mossie A, Hamza L. Prevalence and severity of anemia among school children in Jimma Town , Southwest Ethiopia. BMC Hematol. 2014;14(3).

20. Kakkar R, Negi K. Effect of intervention of IFA on status of Anemia in Adolescent Girl's of Government school of Bhopal. Indian J PrevSoc Med. 2011;42(4).

21. Chandyo R, Ulak M, Adhikari R, Sommerfelt H, Strand T. Prevalence of Iron Deficiency and Anemia among Young Children with Acute Diarrhea in Bhaktapur, Nepal. Healthcare [Internet]. 2015;3(1):593-606. Available from: http://www.mdpi.com/2227-9032/3/3/593/

22. Stevens GA, Finucane MM, De-regil LM, Paciorek CJ, Flaxman SR, Branca F, et al. Global , regional , and national trends in haemoglobin concentration and prevalence of total and severe anaemia in children and pregnant and non-pregnant women for 1995 - 2011: a systematic analysis of population-representative data. Lancet Glob Heal. 2013;16-25.

23. LUSZCZYNSKA A, SCHWARZER AR. SOCIAL COGNITIVE THEORY. In: Conner M, Norman P, editors. PREDICTING HEALTH BEHAVIOUR: RESEARCH AND PRACTICE WITH SOCIAL COGNITION MODELS. Second Edi. New York: McGraw- Hill Higher Education; 2005. p. 127-69.

24. Guled RA, Mamat NM, Belachew T, Abu Bakar WAM, Assefa N. Predictors and Prevalence of Anemia, Among Children Aged 6 to 59 Months in Shebelle Zone, Somali Region, Eastern Ethiopia: A Cross Sectional Study. Int J Dev Res. 2017;7(1):11189-96.

25. Guldan GS, Fan H, Ma X, Ni Z, Xiang X, Tang M. Community and International Nutrition: Culturally Appropriate Nutrition Education Improves Infant Feeding and Growth in Rural Sichuan, China. Am Soc Nutr Sci. 2000;130(January):1204-11.

26. Deribew A, Birhanu Z, Sena L, Dejene T, Reda AA, Sudhakar M, et al. The effect of household heads training about the use of treated bed nets on the burden of malaria and anaemia in under-five children: a cluster randomized trial in Ethiopia. Malar J. 2012;11(8):1-8.

27. Zhang $Y$, Wu Q, Wang W, Velthoven MH Van, Chang S, Han H, et al. Effectiveness of complementary food supplements and dietary counselling on anaemia and stunting in children aged $6-23$ months in poor areas of Qinghai Province, China: a controlled interventional study. BMJ. 2016;6:1-12. 
28. Lechtig A, Cornale G, Ugaz ME, Arias L. Decreasing stunting, anemia, and vitamin A deficiency in Peru: Results of The Good Start in Life Program. Food Nutr Bull. 2014;30(1):37-48.

29. Garc N, Landaeta-jim M, Puche R, Leets I, Carvajal Z, Ibarra C. A Program of Nutritional Education in Schools Reduced the Prevalence of Iron Deficiency in Students. Hindawi Publ Corp Anemia. 2011;

30. Mohammed M, Yaghi A, Yaghi AR. Iron deficiency anemia among kindergarten children living in the marginalized areas of Gaza Strip , Palestine. Brazilian J Hematol Hemotherapy [Internet]. 2014;36(2):132-8. Available from: http://dx.doi.org/10.5581/1516-8484.20140030

31. Bhanushali MM, Shirode AR, Joshi YM, Kadam VJ. An Intervention on Iron Deficiency Anemia and Change in Dietary Behavior among Adolescent Girls. Int J Pharm Pharm Sci. 2011;3(1):40-2.

32. Savita SM, Nath KG, Sharan S. Impact of Education Intervention on Nutrition Knowledge of Iron Deficiency Anaemia among Post-Adolescent Girls. Asian J Dairy food Res. 2013;32(3):214-9.

33. Sanou D, Turgeon-O'Brien H, Desrosiers T. Impact of an Integrated Nutrition Intervention on Nutrient Intakes, Morbidity and Growth of Rural Burkinabe Preschool Children. African J Food Agric Nutr Dev. 2011;11(4):4968-84. 